\title{
Linguistic Evaluation of News Reports on Islamophobic Incidents
}

\author{
Noor Alaa Abdul- Razzk ${ }^{1} \&$ Huda H. Khalil ${ }^{1}$ \\ ${ }^{1}$ Department of English, College of Education for Women, University of Baghdad, Iraq \\ Correspondence: Huda H. Khalil, Department of English, College of Education for Women, University of Baghdad, \\ Jadiriya, Baghdad, Iraq. E-mail: huda.hadi@coeduw.uobaghdad.edu.iq
}

Received: October 20, 2020; Accepted: November 9, 2020; Published: November 13, 2020

\begin{abstract}
This research paper aims at figuring out the way in which the world perceives the Islamophobic incidents. Such a global perception can be obtained from employing a kind of pervasive discourse that is emitted from global institutions and directed to the world in general. Thus, the conducted linguistic evaluation has targeted the news reports as a kind of global media discourse. The linguistic theory employed for language evaluation is Martin and White's (2005) theory of appraisal. Three categories are classified in the appraisal theory: attitude, engagement, and graduation. Attitude is subdivided into effect, judgment, and appreciation; engagement into monogloss and hetergloss, and graduation into force and focus. The methodology works on three variables in the Islamophobic incident: the aggressor, the victim and motive. The orientation of investigation works to identify the attitude of affect directed from the report towards the victim, judgement towards the behavior of the aggressor, and appreciation towards the motive of the incident. The research also identifies the features of these attitudes as being negative or positive, the types (sub- classifications), engagement (monogloss or heterogloss), and graduation (force and focus) of the spotted attitudes. The data consists of twelve news reports selected, according to their topic, from three News agencies: BBC, Independent, and Fox News. The analysis has revealed that, contrary to many claims, news reports tend to adopt a neutral stance towards Muslims and Non- Muslims. They tend to portray the Islamophobic incidents as close to reality as possible.
\end{abstract}

Keywords: appraisal theory, Islamophobia, media discourse, systemic functional linguistics

\section{Introduction}

The events of 9/1 1and the deeds performed by extremists around the world have reshaped the way people view Islam. The impact of these events is still felt in Muslim communities around the world over a decade later. For Muslims living in Western countries, the aftermath has led to widespread discrimination, harassment, dehumanization, and disempowerment, which are normalized through mass media and government policies. Islamophobia is widely believed to be a new concept and has its origins in Britain. While the Oxford English Dictionary indicates that the term was first used in printing in 1991 in the American journal Insight. Other sources and literature indicate that the term first appeared in France in 1925 by Etienne Dinet and Salima ibn Ibrahim, when they wrote "Accès de delire islamophobe". For Alia and Bull $(2005$, p. 29), Islamophobia is not a new phenomenon but it is a transference of old phobia around Africa, the Caribbean and other ethnic minorities. Islamophobia has become an important term. However, there is no universal definition of Islamophobia (Zempi \& Awan, 2016, p. 1). Elahi and khan (2017) acknowledge that it must be recognized that the term "Islamophobia" in itself has caused some confusion. The suffix "phobia" refers to fear or mental illness, rather than the effective selection of discriminatory attitudes and behaviors. The word 'Islam' has created deeper and greater disputes. The most prominent person who expressed this idea is Fred Halliday. Halliday says Islamophobia is confusing and should better correlate with anti-Muslim than anti-Islam because this complexity relates to people more than religion itself. So, he believes that the term that most accurately reflects this idea is "anti-Muslimism" (Halliday, 1999, p. 898).

As a concept and a phenomenon, Islamophobia is becoming popular on account of the publication by the Runnymede Trust of its (1997) report "Islamophobia: A Challenge For Us All". This report has served as the starting point for many subsequent analyses of Islamophobia in Europe and North America (Elahi \& khan, 2017, p. 82). The report became the first source to provide a comprehensive definition of Islamophobia (Allen, 2010, p. 54). Islamophobia refers to "the practical consequences of such hostility in unfair discrimination against Muslim individuals and communities and to the exclusion of Muslims from mainstream political and social affairs" (Runnymede Trust, 1997, p. 4; Elahi \& khan, 2017, p. 7). 
Roald (2004) believes that Islamophobia has many reasons, including political, religious, racist , cultural, and even economic. One of these reasons is what Roald called the scapegoat theory; "groups of people need to physically or mentally oppress contrasting groups or individuals in order to build up group sentiment and adhesion. The legitimization for this kind of tribal conflict might be found in the dynamics between in-groups and out groups" ( Roald, 2004, pp. 54-55). Islamophobia becomes very obvious when Muslims are represented as something that has implication as the "OTHER" instead of something that belongs to "US". Roald (2004, p. 55) mentions that '[c]ultural Islamophobia might be built on an "us" and "them" perspective, where non-Muslims consider cultural traits and social structures in those parts of the world where Islam is prevalent as less acceptable than those of the West.

One can conclude that prejudice and discrimination are the impacts of Islamophobia. They lead to Muslims' voices to be silenced. The consequences of Islamophobia can be multiple and affect the macro and micro levels of society. As a result, these consequences and impacts lead to social and economic hardship for people and society as a whole. "Muslims are precluded from taking part in everyday social interaction which for most other people is largely or entirely unproblematic. Even more obviously, there can be tensions between workplace routines and expectations on the one hand and religious requirements on the other" (The Runnymede Trust, 1997, p. 31).

With the increasing rate of Islamophobic incident, news reporters have found a fertile ground where they can plant interpersonal attitudes which expand to cover nations and societies because of the social power and impact on the public in general. Thus, it is vital to investigate, analyze, identify and diagnose the news reports attitudes towards the Islamophobic incidents that have mainly taken place in the Western counties. The most valid way to achieve that purpose is to evaluate the language employed by the news reports for that purpose in order to fill in the gap of the essential epistemic domain in this respect. Accordingly, this paper employs Martin and White's (2005) theory of appraisal as a kind of discourse semantic analysis. The theory deals with the discourse semantics stratum of language because the contextualization of an attitude extends beyond the limitations of "grammatical boundaries", realized with various grammatical categories and, sometimes, with grammatical metaphor where wording and meaning do not match (Martin \& White, 2005, p. 10).

\subsection{Media Discourse}

Media has its own discourse. Different media also have different discourse. The term "discourse" is originally coined from the Latin word "discursus", which means conversation (Nawaz et al., 2013, p. 328). Crystal (2008, p. 148) defines discourse as "a set of utterances which constitute any recognizable speech event". Discourse is a logical grouping of speech or writing. It represents a particular method of representation by means of a set of expressions that facilitate the language of speaking about a specific type of knowledge about the topic (Kress, 1985, pp. 6-7). Foucault (1979), who is one of the theorists most often referred to when discussing the term discourse, argues that discourse builds the topic, defines and produces things from the knowledge. Discourse also influences how ideas are put into practice and used for organizing the behavior of others. Thus, meaning is built primarily through discourse and has no meaning outside discourse (Hall, 1997, p. 44). The discourse is identical to what sociologists call "ideology". It is a collection of data or beliefs that produces knowledge that serves the goals of a particular group or class (Hall \& Gieben, 1992, p. 291). Accordingly, one can say that discourses are not simple words that reflect or describe people's experiences. Some of the discourses have a strong influence on society by having the means to regulate the sense of reality and the idea of identity (Elgamri, 2008, pp. 73-74).

Media discourse is the communication that takes place in the media, be it print or electronic media (Afroz, 2016, p.7). It can refer to the entirety of how reality is represented in broadcast media and print media from television to newspaper (O'Keeffe, 2006, p. 1). Williams $(2003$, p. 6) states that media help people negotiate the meanings of what is going on in the world; "[t]hey help us to learn about the values, beliefs and norms of our societies as well as assist us to develop our own sense of identity". Van Dijk (2000) states that media discourse is the main source of people's knowledge, attitudes and ideologies (Van Dijk, 2000, p. 36). Every aspect of society is dominated by ideology. It can also be seen as a channel through which the ruling elite attempts to trick and control the ruled groups. Ideology plays a major role in the production of media discourse. In order to reproduce the dominant ideology, media statements may include stereotypes, discrimination, or exclusion. From time to time, media may create symbolic violence that includes the use of motivational vocabulary, libel, inhumane phrases, offensive words or expressions (Burak, 2018, pp. 55-54).

\subsection{News Discourse}

In today's world, news has become an important part of life because people are updated about current events in the world (Afroz, 2016, p. 6). In the field of media, news is defined as a "report of a current happening or happenings in a newspaper, on television, on radio, or on a web site" (Danesi, 2009, p. 212). News texts are framed by news 
agency goals, agendas and the type of reception expected from the audience. Their creation involves a complex process that includes regulatory, economic, social and political factors (Grazia Busa, 2014, p. 13).

News stories and their structure are chosen according to what are called news values. The values by which events or facts are evaluated are of major importance (Fowler, 1991, p. 13; Bednarek, 2006, p. 16). In other words, "news is not simply that which happens, but that which can be regarded and presented as newsworthy" (Fowler 1991, p. 13). News language influences and shapes the readers' perceptions as well. 'The news media creates frames of interpretation through which we understand "reality," but the reality in question is a construction that reflects the biases and ideologies of individual journalists and the media organizations that employ them' (Green, 2015, p. 234). By choosing the material available, inserting or excluding information, newspapers are already providing their readers with an explanation of the outside world; a story that reflects conscious or unconscious thoughts and beliefs, not the real thing (Nordlund, 2003, p. 6).

\subsection{Islamophobia in the Media}

The knowledge of people about Islam is mainly gained from the media and the images it supplies to the masses and consumers. (Green, 2015, p. 233). Western media are generally accused of the incline to build a specific image of Islam by describing it as a threat to the West. Said (1997, p. 169) said that media selectively control and filter information to set what people should learn about Islam. He asserted that the dominant media image was of "repressive", "backward," and "dangerous" Islam and pictures that he said were centuries old and were repeated by the media. He states that "much of what one reads and sees in the media about Islam represents the aggression as coming from Islam because that is what 'Islam' is" (Said, 1997, p. xxii). Saeed (2007, p. 454) argues that the media does depict negative portrayals of Muslims and Islam. These portrayals are transmitted to a large number of people around the world. Thus, the media is responsible for promoting "anti-Muslim racism".

The image of Islam can be considered largely through the media as domination by organizations or even people who can produce or create discourses. They impose their views on these discourses, and, thus, cause ordinary people to absorb it without realizing the "stereotypical ideology" of this thing according to the way text producers think of it .It is a matter of getting society to take on what imposes on them by the authority of the text, and therein lies the problem of Islamophobia and the media (Shukur, 2017, p. 31).

Studies of the framing of Islam in the Western media have shown two predominant themes; these are terrorism and the persecution of women. Terrorism becomes the most memorable topic in media stories about Islam. (Green, 2015, p. 235). Powell (2011) also explains the ways in which media portrays "Muslim terrorists" versus " nonMuslim domestic terrorists". Media describes Muslim terrorists as violent or extremist rather than describing nonMuslim white terrorists in this way. Moreover, gender perspectives are also evident in media representation of Muslims. The reports of Muslim women particularly concentrate on their persecution and their status as victims. Stereotypical Muslim women are portrayed in the Western media as a victim of violence or sexual discrimination or both by angry Muslim men and sometimes other women. The concern of the media for persecuted Muslim women is also evident in the reports that display the veil. In media, the veil represents the symbol of the repression of women and the uncivilized and backwardness nature of Islam (Green, 2015, pp. 240-243).

\subsection{Appraisal Theory}

In recent years, linguists have paid great attention to linguistic evaluation because of its importance as an aspect and function of the human language. Generally, evaluation is about the way speakers encode or implicitly convey different types of subjective opinions in the discourse and, thus, attempt to achieve some agreement between values concerning what is represented (Hart, 2014, p.43). Language evaluation is essential for gaining better objective insights and appreciation for particular non- linguistic social or political issues in the world. (Mei et al., 2015, pp. 178-179).

Hart (2014, p. 43) states that evaluative phenomena in discourse can be found under several different headings, including "stance" and "appraisal". The more developed framework, and direct expansion of Halliday's Systemic Functional Linguistics (SFL), is appraisal theory (Martin \& White, 2005). SFL, dealing with how users share meanings in various social contexts, is a theory of meanings defined as a collection of choices. These choices are defined by system networks and are designed to demonstrate how language consists of sets of connected options. The systems reflect the choices available in a given situation from which, language users make choices that are relevant to the situation (Young, 2011, p. 629). SFL is a viewpoint for both externally representing language as a social and cultural phenomenon and internally as a formal meaning-expressing mechanism. The theory is designed not only to understand how people communicate through language with each other, but also to provide a technique for examining several kinds of discourse. SFL views language theoretically as functionally organized; these functions technically referred to as metafunctions (Young, 2011, p. 627). SFL recognizes three modes of meaning 
(metafunctions) which work jointly in all utterances. These are the textual, the ideational and the interpersonal. Appraisal theory is developed in order to organize and verify the interpretation of interpersonal meanings in texts (Martin \& White, 2005, p. 1).

According to Martin \& Rose (2003, p. 26), "[w]e use the resources of APPRAISAL for negotiating our social relationships, by telling our listeners or readers how we feel about things and people" (Martin \& White 2005, p. 1). The basic idea of appraisal theory is that it helps to define the self-existence of writers/speakers in texts as they adopt attitudes toward both the material they provide and those they communicate with.

Appraisal attitude itself can be subdivided into three main headers: "attitude", "engagement" and "graduation" (White, 2001, p. 4; Martin \& Rose, 2003, p. 25; Martin \& White, 2005, p. 35).

\subsubsection{Attitude}

Attitude has to do with evaluating "our feelings, including emotional reactions, judgements of behaviour and evaluation of things" (Martin \& White, 2005, p. 35). It is divided into three sub-systems: "Affect", "Judgement" and "Appreciation". Attitude can be realized explicitly, through the lexico- grammar (inscribed) or implicitly, through ideational meanings (invoked) (Martin \& White, 2005, p. 61). An appraisal that is invoked occurs when a speaker or writer tells people something that is not directly evaluated but that is intended to invoke the situation.

\section{A. Affect}

Affect values supply resources through which speakers can show how this phenomenon emotionally affects them (White, 2001, p. 10). For example, The girl was very happy (expressing attitude by interpreting an emotional response). Martin and White (2005, p. 46) subdivide affect into three different categories: (a) affect as "quality" (e.g. the captain was sad/happy), (b) affect as "process" (e.g. the captain wept/cheered) and (c) affect as "comment" (e.g. sadly, luckily, he had to go).

Commenting on the emotions involved in affect, Martin \& White (2005, pp. 46-49) state that the emotions that are culturally interpreted can be of positive or negative feelings; for example, The girl was happy (Positive), It was a very sad day (Negative). The emotions could come in the form of a change of feeling with linguistic or paralinguistic appearance. It could also be a mental state or process. They are interpreted depending on their orientation towards the trigger. One can infer people's feelings directly or indirectly from their behavior. Thus, affect can be implicit or explicit. Emotions are classified into three groups: un/happiness, in/security and dis/ satisfaction, for example, The child felt sad/happy (un/happiness), The child felt anxious/confident (in/security), The child felt fed up/absorbed (dis/satisfaction).

\section{B. Judgement}

Judgement is made when the speaker presents an assessment of some human participants regarding the participants' actions or behaviour (White, 2001, p. 6). Martin and White (2005, p. 52) illustrate that, like Affect, values of judgement can be either positive or negative (e.g. brave versus cowardly) and they may be judged explicitly or implicitly (Martin \& Rose, 2003, p. 32). In addition, meanings can be located on a sliding scale of intensity from low to high values (e.g. He is a good player, a skilled player, a brilliant player).

White (2001), Martin and Rose (2003), Martin and White (2005) and Thompson (2014) express that the system of judgement can be of two types, those concerned with "social esteem" and those focused on "social sanction". Social esteem involves assessments whereby the person who is judged is reduced or raised at the discretion of his community, but does not have any legal or moral implications (e.g. His father told him that he should not be so sardonic) (White, 2001, p. 11). Judgements of esteem are rightfully associated with such aspects as "normality" (Stressing how unusual a person is, and the extent of their usual behaviuor), "capacity" (dealing with how capable someone is) and "tenacity" (showing how dependable someone is) (White, 2001, p.11; Martin \& White, 2005, p. 52).

By contrast, the social sanction includes matters of legality and morality. From a legal viewpoint, they are considered as crimes. From a religious viewpoint, breaches of social sanction are sins. Thus, breach of social sanction is the risk of legal or religious punishment (e.g. My manager is corrupt and unjust) (White, 2001, p. 11). Judgments of sanction circle around both "veracity" (demonstrating how truthful somebody is) and "propriety" (bringing to the fore the ethical aspect of someone and someone's behaviuor) (White, 2001, p. 11; Martin \& White, 2005, p. 52).

\section{Appreciation}

Martin and White (2005, p. 56) view appreciation in line with evaluations one makes as far as things are concerned, especially those things which people make and the performance they are engaged in. It also includes evaluations 
of natural phenomena. Like both affect and judgement, values of appreciations have either positive or negative (e.g. beautiful versus ugly). They can also be located on the cline of low to high force/intensity (e.g. pretty, beautiful, exquisite) (Martin \& White, 2005, p. 56).

Appreciation can be divided arbitrarily into "reactions" to things (the product/process is evaluated in terms of the impact it makes or its quality), their "composition" (the product or process is evaluated according to its makeup, according to whether it conforms to various conventions of formal organisation), and their "value" (product or process is evaluated according to various social conventions) (White, 2001, p. 13; Martin \& White, 2005, p. 56).

\subsubsection{Engagement}

Engagement is the second appraisal system that deals with linguistic resources through which speakers or writers adopt a position toward the valuable attitudes referred to in the text. Instead of heading towards grammatical forms, the trend is towards meanings in context and rhetorical influences. As a result, it combines a lexically and grammatically diverse selection of locutions on the basis that they all work to direct the writer or speaker to the value of the positions presented in the text (Martin \& White, 2005, pp. 93-94).

Utterances are either monoglossic (bare assertions) with "no reference to other voices and viewpoints" (Martin \& White, 2005, p. 99), or heteroglossic, that is, they "invoke or allow for dialogistic alternatives" (Martin \& White, 2005, p. 100). Martin and Rose (2003, p. 49) point that "we will use the term heterogloss where the source of an attitude is other than the writer, and monogloss ('single voice') where the source is simply the author".

\subsubsection{Graduation}

Graduation is the third dimension of appraisal. It is related to the values which scale the meanings along with two possible frameworks. It can place the meanings on a scale from low to high intensity, or from the essence to marginal membership of a category (White, 2001, p. 24). It contains meanings that in the literature have been labeled as intensifiers, downtoners, boosters and hedges such as, slightly, rather, very, entirely and sort of/kind of, etc. They can be considered as mechanisms by which speakers/writers can present themselves as more or less powerfully aligned with the value offered by the text, thus, determining their place concerning the communities of shared values and beliefs linked with these positions (Martin \& White, 2005, p. 94). Scaling is not restricted to an explicit value which can be carried by some isolating lexical items such as very, somewhat, etc. It also be considered in an implicit value. White (2001, p. 24) says that "[o]nce we allow for an implicit semantic, we discover that scaling, in terms of the raising or lowering of intensity, operates across the APPRAISAL system and is not confined within a specific sub-domain".

Accordingly, graduation works across two "axes of scalability" focus and force (Martin \& Rose, 2003, p. 137). From an experiential perspective, focus typically applies to categories that cannot be scaled. These are specific categories (either - or). "[F]ocus is about resources for making something that is inherently non-gradable gradable" (Martin \& Rose, 2003, p.46). Under focus, the specification can up-scale, or sharpen. Accordingly, the values operate to show that the value represented has a prototype status. The specification can also downscale, or soften, to show that an example has only marginal membership in the category (Martin \& White, 2005, p. 138).

The second major category of graduation is force. Force covers evaluations with respect to the degree of intensity. Scaling of qualities and processes is referred to as "intensification" (Martin \& White, 2005, p. 140). Martin and Rose (2003, p. 43) clarify that "[i]ntensifies make it possible for us to compare things - to say how strongly we feel about someone or something, by comparison to something else. These comparisons are possible because the worth of things is gradable". Intensification is divided into two broad "lexicogrammatical" categories, "isolating" and "infusing". The difference between them is whether the up-scaling or down-scaling is achieved by an isolated individual component that performs the function of determining the level of intensity such as somewhat miserable, quite possible, very possible, or whether the sense of up or down-scaling is complemented with a meaning that works for some other semantic function (Martin \& White, 2005, p. 141).

Rather than to qualities and processes, assessments of amount (e.g. size, weight, strength, number), the extent covering scope in time and space, and proximity in time and space are applied to entities. These assessments are termed "quantification" (Martin \& White, 2005, p. 149). Quantification can be presented by an isolated term that acts as a modifier of the graduated entity such as many, large, heavy, near. At the same time, there are locutions that are similar to the infusing formulation in that the assessment of quantity is carried by the noun head itself not by a modifier (Martin \& White, 2005, p. 151). 
The key appraisal systems are outlined in Figure 1:

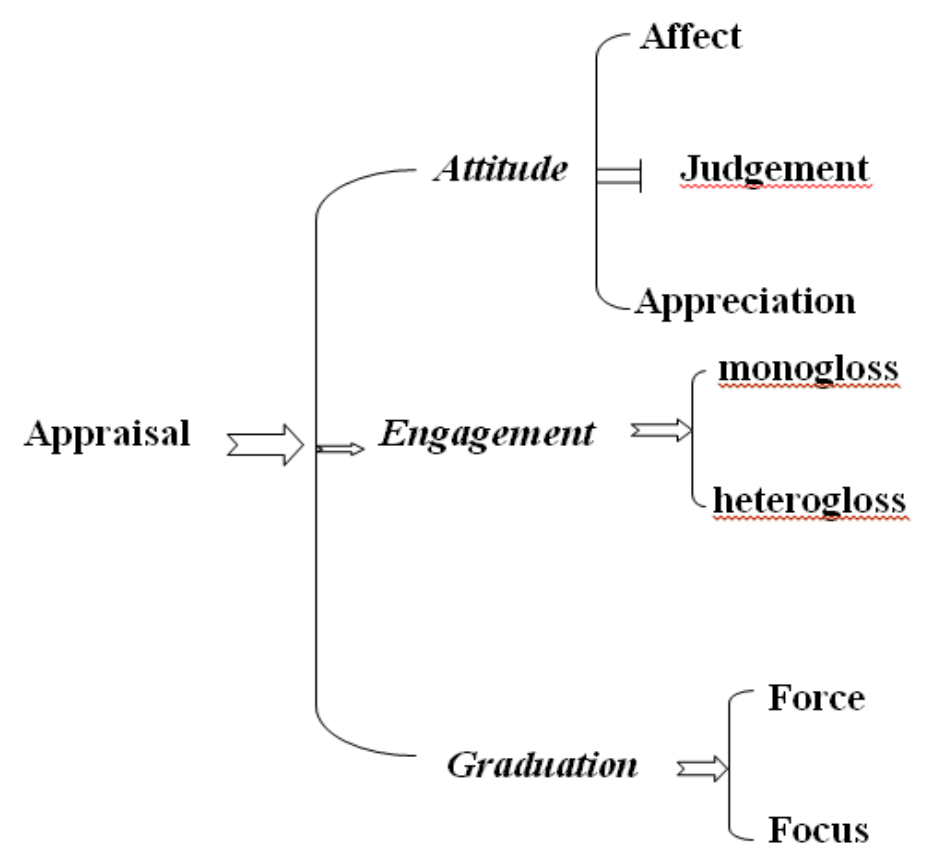

Figure 1. Illustration of appraisal subsystems (Martin \& Rose, 2003, p.5)

\section{Method and Data Description}

The methodological framework designed for analysis is based on Martin and White (2005) theory of appraisal. The analysis integrates qualitative and quantitative domains to get better objective results. The steps conducted for the application of the methodological framework are as follows:

1. Identifying the three vital parameters in the Islamophobic incidents: victim, aggressor's behavior, and the motive of the incident. For example, the victim could be a woman who has been attacked for wearing hijab, the aggressor's behavior could be pulling off the woman's hijab and the motive could be the hijab itself as an indication of Islam;

2. Uncovering the attitudes rooted in the data towards the three parameters. This is done on the bases of the three subsystems of attitude (affect, judgement and appreciation). Affect is identified for the victim's feeling, judgement for the aggressor's behavior and appreciation for the motive of the incident as illustrated in figure 2:

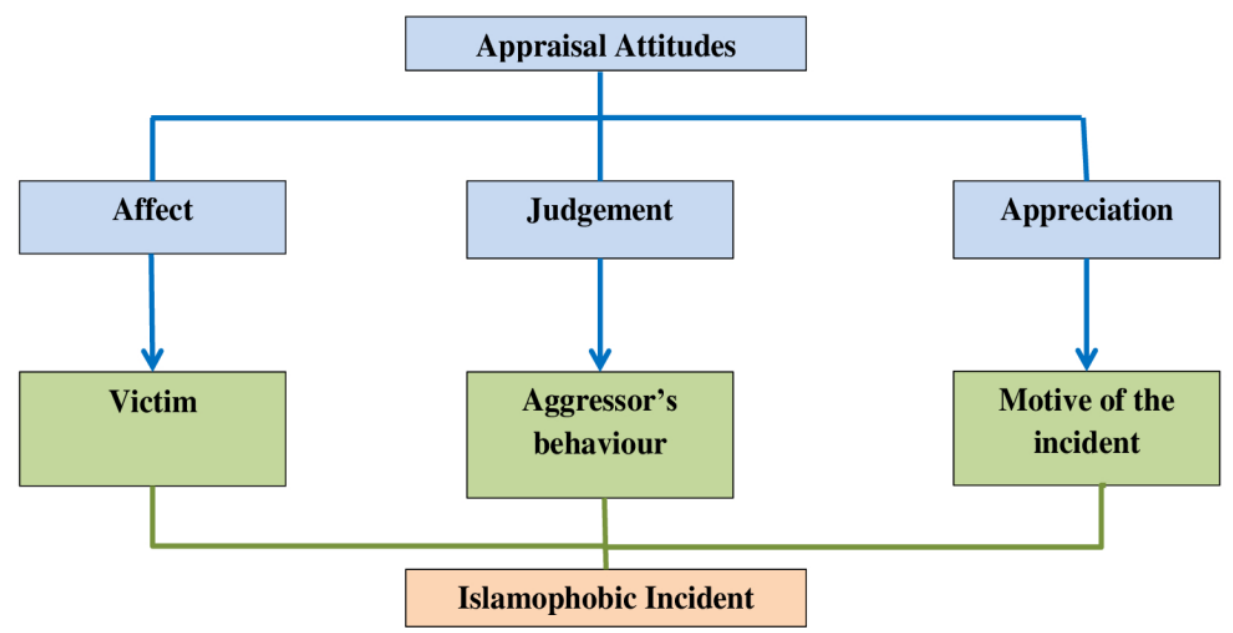

Figure 2. The identification of attitude for the three parameters of the Islamophobic incident 
3. Identifying the polarity of each attitude, whether positive or negative, depending on the lexicalization clues of the co- text surrounding the sentences where the attitudes are located;

4. Identifying the types (sub- classifications) of affect, judgement and appreciation depending on certain linguistic clues that vary from one sentence to the other;

5. Identifying engagement for each of the three attitudes (affect, judgement and appreciation), whether the engagement is monogloss (echoing the reporter's voice) or heterogloss (echoing voices other than the reporter's);

6. Identifying the graduation for each of the three attitudes (affect, judgement and appreciation), whether the graduation is achieved through force (up or down) or through focus (softening or sharpening);

7. After analyzing the whole data, statistics are put in tables to figure out the results obtained from steps two, three, five and six. Separate statistical tables have been designed for each attitude that is assigned to evaluate a particular parameter. A special table has been design to obtain the statistical results of step four that displays the subclassifications of each attitude;

Basically, the data is a collection of online news articles on Islamophobic incidents around the world. The articles that are available online have been selected according to their topic. They represent a handy source of news, ideologies and attitudes that are freely available online. Twelve articles have been downloaded from the websites of three news agencies: BBC News (British Broadcasting Corporation), Independent (British online newspaper) and Fox News (American conservative cable television news channel). Four articles have been selected from each agency on the bases that these agencies are globally well known and put their news online, a matter that increases their visibility.

\section{Results}

This section presents the results and the discussions in correspondence with the reporters' employment of Attitude, Engagement and Graduation resources respectively in the twelve news reports selected from three news agencies: BBC, Independent and Fox News.

Table 1. Statistical analysis of affect towards the victim's feeling

\begin{tabular}{|c|c|c|c|c|c|c|c|c|c|c|c|c|c|}
\hline \multicolumn{14}{|c|}{ Affect towards the victim's feeling } \\
\hline \multicolumn{7}{|c|}{ Positive } & \multicolumn{7}{|c|}{ Negative } \\
\hline \multicolumn{2}{|c|}{ Engagement } & \multicolumn{5}{|c|}{ Graduation } & \multicolumn{2}{|c|}{ Engagement } & \multicolumn{5}{|c|}{ Graduation } \\
\hline \multirow{2}{*}{$\begin{array}{l}3 \\
3 \\
0 \\
0 \\
09 \\
0 \\
0 \\
0 \\
0\end{array}$} & \multirow{2}{*}{ 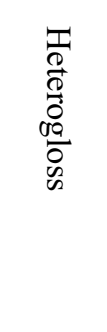 } & \multicolumn{2}{|c|}{ Force } & \multirow{2}{*}{ 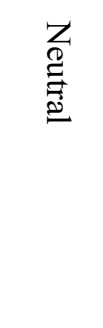 } & \multicolumn{2}{|c|}{ Focus } & \multirow{2}{*}{$\begin{array}{l}3 \\
0 \\
0 \\
0 \\
00 \\
0 \\
0 \\
0 \\
0\end{array}$} & \multirow{2}{*}{ 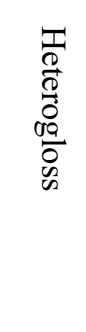 } & \multicolumn{2}{|c|}{ Force } & \multirow{2}{*}{ 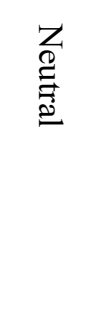 } & \multicolumn{2}{|c|}{ Focus } \\
\hline & & C & $\begin{array}{l}\text { ஏ๐ } \\
\vdots \\
\vdots\end{array}$ & & 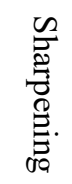 & 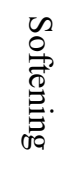 & & & 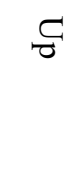 & 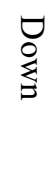 & & 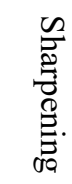 & 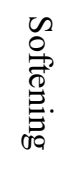 \\
\hline 0 & 1 & 0 & 0 & 1 & 0 & 0 & 3 & 28 & 19 & 0 & 15 & 0 & 0 \\
\hline 0 & $100 \%$ & 0 & 0 & $100 \%$ & 0 & 0 & $10 \%$ & $90 \%$ & $56 \%$ & 0 & $44 \%$ & 0 & 0 \\
\hline \multicolumn{7}{|l|}{2} & \multicolumn{7}{|c|}{65} \\
\hline \multicolumn{7}{|c|}{$3 \%$} & \multicolumn{7}{|c|}{$97 \%$} \\
\hline
\end{tabular}

Table 2. Statistical analysis of judgement towards the aggressor's behavior

\begin{tabular}{|c|c|c|c|c|c|c|c|c|c|}
\hline \multicolumn{10}{|c|}{ Judgement for the aggressor's behavior } \\
\hline \multicolumn{5}{|c|}{ Positive } & \multicolumn{5}{|c|}{ Negative } \\
\hline \multicolumn{2}{|c|}{ Engagement } & \multicolumn{3}{|c|}{ Graduation } & \multicolumn{2}{|c|}{ Engagement } & \multicolumn{3}{|c|}{ Graduation } \\
\hline $\begin{array}{l}3 \\
0 \\
0 \\
0\end{array}$ & $\begin{array}{cc}\infty a & \mathbb{T} \\
0 & 0 \\
0 & 0 \\
\infty & 0 \\
\infty & 0\end{array}$ & Force & 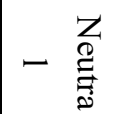 & Focus & 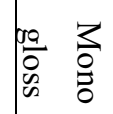 & 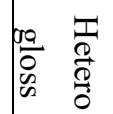 & Force & $-\underset{\substack{Z \\
\Xi}}{\stackrel{Z}{Z}}$ & Focus \\
\hline
\end{tabular}




\begin{tabular}{|c|c|c|c|c|c|c|c|c|c|c|c|c|c|}
\hline & & $\delta$ & $\begin{array}{l}\text { Ð } \\
\vdots \\
\vdots\end{array}$ & & 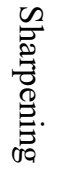 & 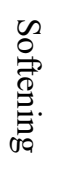 & & & $\mathcal{S}$ & $\begin{array}{l}\text { Ð } \\
\vdots \\
\vdots\end{array}$ & & 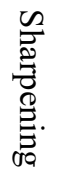 & 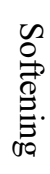 \\
\hline 0 & 2 & 0 & 0 & 2 & 0 & 0 & 7 & 20 & 1 & 0 & 26 & 0 & 0 \\
\hline 0 & $100 \%$ & 0 & 0 & $100 \%$ & 0 & 0 & $26 \%$ & $74 \%$ & $4 \%$ & 0 & $96 \%$ & 0 & 0 \\
\hline \multicolumn{7}{|c|}{2} & \multicolumn{7}{|c|}{54} \\
\hline \multicolumn{7}{|c|}{$4 \%$} & \multicolumn{7}{|c|}{$96 \%$} \\
\hline
\end{tabular}

Table 3. Statistical analysis of appreciation towards the motive of the incident

\begin{tabular}{|c|c|c|c|c|c|c|c|c|c|c|c|c|c|}
\hline \multicolumn{14}{|c|}{ Appreciation towards the motive of the incident } \\
\hline \multicolumn{7}{|c|}{ Positive } & \multicolumn{7}{|c|}{ Negative } \\
\hline \multicolumn{2}{|c|}{ Engagement } & \multicolumn{5}{|c|}{ Graduation } & \multicolumn{2}{|c|}{ Engagement } & \multicolumn{5}{|c|}{ Graduation } \\
\hline \multirow{2}{*}{ 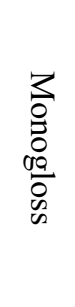 } & \multirow{2}{*}{ 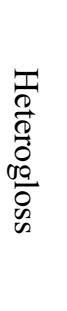 } & \multicolumn{2}{|c|}{ Force } & \multirow{2}{*}{ 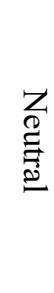 } & \multicolumn{2}{|c|}{ Focus } & \multirow{2}{*}{ 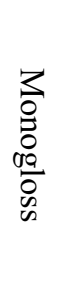 } & \multirow{2}{*}{ 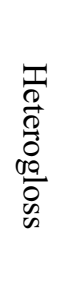 } & \multicolumn{2}{|c|}{ Force } & \multirow{2}{*}{ 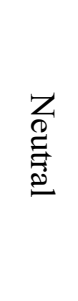 } & \multicolumn{2}{|c|}{ Focus } \\
\hline & & $S$ & 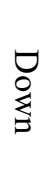 & & 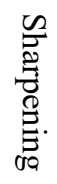 & 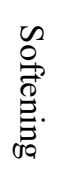 & & & C & 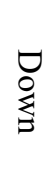 & & 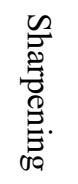 & 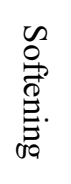 \\
\hline 0 & 0 & 0 & 0 & 0 & 0 & 0 & 3 & 32 & 9 & 0 & 20 & 6 & 2 \\
\hline 0 & 0 & 0 & 0 & 0 & 0 & 0 & $9 \%$ & $91 \%$ & $24 \%$ & 0 & $55 \%$ & $16 \%$ & $5 \%$ \\
\hline \multicolumn{7}{|c|}{0} & \multicolumn{7}{|c|}{72} \\
\hline \multicolumn{7}{|c|}{$0 \%$} & \multicolumn{7}{|c|}{$100 \%$} \\
\hline
\end{tabular}

Table 4 below, presents the statistical analysis of the types (sub- classifications) of Affect, Judgement and Appreciation detected in the news reports:

Table 4. The statistics for the types (sub- classifications) of Affect, Judgement and Appreciation

\begin{tabular}{|c|c|c|c|c|c|c|c|c|c|c|}
\hline \multicolumn{3}{|c|}{ Affect } & \multicolumn{5}{|c|}{ Judgement } & \multicolumn{3}{|c|}{ Appreciation } \\
\hline 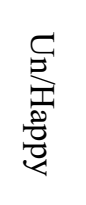 & 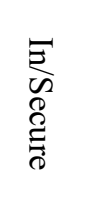 & 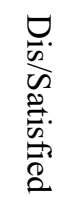 & 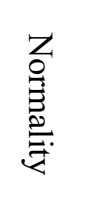 & \begin{tabular}{l}
$\Omega$ \\
\multirow{2}{*}{} \\
$\stackrel{0}{*}$ \\
$\gtrless$
\end{tabular} & $\begin{array}{l}\vec{\theta} \\
\stackrel{8}{0} \\
\stackrel{0}{\otimes}\end{array}$ & 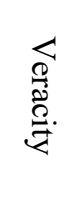 & $\begin{array}{l}\stackrel{7}{0} \\
\stackrel{0}{0} \\
\stackrel{0}{*}\end{array}$ & $\begin{array}{l}\overparen{0} \\
\stackrel{0}{0} \\
\stackrel{0}{0} \\
0\end{array}$ & 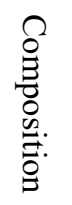 & 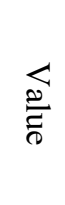 \\
\hline 4 & 26 & 2 & 3 & 0 & 2 & 0 & 24 & 32 & 2 & 1 \\
\hline $13 \%$ & $81 \%$ & $6 \%$ & $10 \%$ & 0 & $7 \%$ & 0 & $83 \%$ & $91 \%$ & $6 \%$ & $3 \%$ \\
\hline
\end{tabular}

Based on the tables above, it can be said that all types of attitude; affect, judgement, and appreciation are utilized in the reports analyzed. The majority of attitudes are negative. The negative attitudes score $97 \%$ for affect, $96 \%$ for judgement, and $100 \%$ for appreciation. This means that the reporters focus more on the negative sides of the evaluation. As for affect, the reporters tried to concentrate on showing the victim, whether a woman or a man, in the position of the vulnerable person who feels insecure and fears the unknown and not a person who is self- 
confident and faces situations with courage. As for the judgment, people who commit such offences are often characterized as suffering from abnormal behaviour, contrary to their opinion, as they are proud of themselves and consider these crimes as a kind of service to their country. It is natural that these incidents are portrayed with negative descriptions, that is, with regard to appreciation, as they are among the crimes that have a great effect on the person and on society as a whole.

The forms of engagement used by reporters, whether with affect, judgment or appreciation, are highly heteroglossic rather than monoglossic. The percentage is $90 \%$ in affect, $74 \%$ in the judgment and $91 \%$ in appreciation. The largest percentages are with affect and appreciation, because with such sensitive issues, reporters are trying to free themselves from responsibility. They stress their point of view and, at the same time, create a communicative environment for the purpose of persuading readers.

The findings also demonstrate, with regard to graduation, that the form used most of the time, especially with judgment and appreciation, is neutral more than force and focus, as its percentage in judgment is $96 \%$ and in appreciation is $55 \%$. As for the affect, the type that is mostly used is force (56\%) to show how strongly the victims feel about these incidents.

The victims' negative feelings portray fear and insecurity. Therefore, focusing on the form of affect used in these reports, it can be found that in/security shows high score with $81 \%$. As for the form of judgment, because such behaviors are considered immoral and the offenders must be kept responsible by law, the form used most of the time is propriety ( $83 \%$ ). As for appreciation, the subtype is dominant with the score of $91 \%$.

\section{Discussion}

As a global genre with considerable social power, news reports stand as a signpost for the general public stance towards general issues that are of global interest. This genre, as an effective media form, has played an essential role in shaping the public opinion on Islam. The image of Islam can be considered largely through the media as dominated by organizations or even people who can produce or create discourses.

Evaluating the language of news reports on Islamophobic incidents, the victims in these incidents are presented as weak helpless figures who are powerless and miserable. They face tough situations cowardly and feel insecure all the time. Unfortunately, the reporters are portraying the truth about people who fled their countries searching of more secure places to live and raise their children. But they found themselves facing a different kind of threat; the nightmare of Islamophobia which came as a natural consequence for the mistaken view on Islam that extremists around the world have created.

Judgement towards the aggressors' behavior has also been mainly negative. The aggressors' deeds are described in an objective way as part of the negative conduct that the societies, in general, condemn. The Muslim communities who live in foreign countries should not be victims for aggressive acts performed by others (extremists). The same applies to appreciating the Islamophobic incident itself. Such incidents are also presented negatively. This comes counterpart to what some individuals claim that media encourages violence towards Muslims in an indirect way. Though media coverage of extremists attacks around the world has contributed to promoting prejudice towards Muslims (Ryzik, 2016; Ward, 2016; Poniewozik, 2017), there are unbiased states of balance that deserve to be shed light on.

To sustain the reports' objectivity, the reporters choose to build their text on heterogloss bases where they (reporters) keep themselves in the shadow as message holders. Objectivity is also sustained through graduation by inclining mostly to stay neutral concerning both the force and focus of the attitudes expressed.

According to the findings, table 4 shows that security issues have topped the list of affect types. This finding reflects the kind of psychological need that Muslims long for through being refugees and emigrants in other countries. There is focus on this kind of effect since it reflects the major need that urged Muslims to flee their countries for, but they could not satisfy that need. As for the judgement of the aggressors' behavoiur, the propriety type is mostly dominant. This type elicits ethical issues that go counterpart to the general orientation of all communities.

News reports, thus, use ethics, as a sensitive subject to raise censure against the aggressors' behaviour. The type of appreciation for the motive of the incident is mainly a negative reaction to previous attacks performed by extremist who falsely claim to strive for Islam. Such kind of appreciation may deliver the message that innocent Muslims should not be punished for criminal acts performed by others who claim to be genuine Muslims.

However, one would wonder how non-Muslims would feel and react if they were attacked by extremists. Similar research methodology is suggested in this paper to be conducted on attack incidents performed by extremist against non- Muslims to compare the results with the ones obtained in the present paper. 


\section{Reference}

Afroz, S. (2016). Media Discourse: Understanding the Language of News. (Master's Thesis, BRAC University, Department of English and Humanities). Retrieved from http:/hdl.handle.net/10361/7819

Alia, V., \& Bull, S. (2005). Media and Ethnic Minorities. Edinburgh: Edinburgh University Press.

Allen, C. (2010). Islamophobia. Farnham : Ashgate.

Bednarek, M. (2006). Evaluation in Media Discourse. Analysis of a Newspaper Corpus. New York: Continuum.

Burak, B. (2018). Media Discourse ,Ideology and Print Media in Turkey. e-Journal of New Media, 2(2), 53-62. https://doi.org/10.17932/IAU.EJNM.25480200.2018.2/2.53-62

Crystal, D. (2008). A dictionary of linguistics and phonetics. Oxford: Blackwell. https://doi.org/10.1002/9781444302776

Danesi, M. (2009). Dictionary of media and communications. New York: Sharpe, Inc.

Elahi, F., \& Khan, O. (2017). Islamophobia: Still a challenge for us all, A 20th-anniversary Report, Runnymede: Intelligence for a Multi-ethnic Britain. Retrieved from https://www.runnymedetrust.org/uploads/Islamophobia\%20Report\%202018\%20FINAL.pdf

Elgamri, E. (2008). Islam in the British Broadsheets: The Impact of Orientalism on Representations of Islam in the British Press. Reading: Ithaca Press.

Eric, W. (2016). "How Can We Fight Islamophobia in America?" Ford Foundation, March 7, 2016, https://www.fordfoundation.org/ideas/equals-change-blog/posts/how-can-we-fight-islamophobia-inamerica/

Fowler, R. (1991). Language in the news: Discourse and ideology in the press. New York: Routledge. https://doi.org/10.2307/415093

Grazia, B. M. (2014). Introducing the Language of the News: A student's guide. New York: Routledge.

Green, T. H. (2015). The Fear of Islam: An Introduction to Islamophobia in the West. New York: Fortress Press. https://doi.org/10.2307/j.ctt12878h3

Hall, S. \& Gieben, B. (eds.) (1992). Formations of Modernity. Polity Press: Cambridge.

Hall, S. (ed.) (1997). Representation: Cultural Representations and Signifying Practices. SAGE Publications: London.

Halliday, F. (1999). 'Islamophobia' reconsidered. Ethnic and Racial Studies, 22(5), 892-902. http://doi.org/10.1080/014198799329305

Hart, C. (2014). Discourse, Grammar and Ideology: Functional and Cognitive Perspectives. London: Bloomsbury.

James, Poniewozik (2017). “'24: Legacy,’ A One-Hour Super Bowl Ad for Islamophobia,” New York Times, February, 6, 2017. https://www.nytimes.com/2017/02/06/arts/television/muslimterrorists-24-trump.html.

Kress, G. (1985). Linguistic Processes in Sociocultural Practice. Victoria: Deakin University Press.

Martin, J. R., \& Rose, D. (2003). Working with discourse: Meaning beyond the clause. London: Continuum Press

Martin, J. R., \& White, P. R. R. (2005). The Language of Evaluation: Appraisal in English. New York: Palgrave Macmillan Ltd. https://doi.org/10.1057/9780230511910

Mei, Z., Zhang, R., \& Yu, B. (2015). An Appraisal Analysis of Reports about Chinese Military Affairs in the New York Times. In Zou B., Smith S., Hoey M. (eds.) Corpus Linguistics in Chinese Contexts. London: Palgrave Macmillan, pp. 178-200. https://doi.org/10.1057/97811374440037_10

Ryzik, M. (2016). “Can Television Be Fair to Muslims?” New York Times, November 30, 2016, http://www.nytimes.com/2016/11/30/arts/television/can-television-be-fair-to-muslims.html.

Nawaz, S., Bilal, H. A., Kalsoom, M., Fayyaz, Z. \& Nayyar, H.( 2013). Media Discourse and Their Implicit Ideologies. Asian Journal of Social Sciences \& Humanities, 2(2), 328-337.

Nordlund, M. (2003). An essay of Linguistic Manipulation: An Analysis of How Attitudes are Displayed in New Reporting. Lulea: University of Technology.

O'Keeffe, A. (2006). Investigating Media Discourse. London: Routledge. https://doi.org/10.4324/9780203015704

Powell, K. A. (2011). Framing Islam: An Analysis of U.S. Media Coverage of Terrorism Since 9/11. Communication Studies, 62(1), 90-112. https://doi.org/10.1080/10510974.2011.533599 
Roald, A. (2004) New Muslims in the European context - The Experience of Scandinavian Converts. Leiden: Brill.

Runnymede, T. (1997). Islamophobia: A Challenge for us all. Report of The Runnymede Trust Commission on British Muslims and Islamophobia.

Saeed, A. (2007). Media, racism and Islamophobia: The representation of Islam and Muslims in the media. Sociology Compass, 1(2), 443-462. https://doi.org/10.1111/j.1751-9020.2007.00039.x

Said, W. E. (1997). Covering Islam: How the media and the experts determine how we see the rest of the world. London: Vintage Books.

Shukur, S. H. (2017). Hyperbole in Reporting Islamophobia in the American Journals. (Unpublished Master Thesis, Mustansiriyah University, Baghdad, Iraq).

Thompson, G. ( 2014). Introducing Functional Grammar. New York: Routledge. https://doi.org/10.4324/9780203785270

Van Dijk, T. A. (2000). New(s) racism: A discourse analytical approach. In S. Cottle (ed.), Ethnic minorities and the media. England: Open University Press, pp. 33-49.

White, P. P. R. (2001). An introductory tour through Appraisal Theory. Retrieved from http://www.grammatics.com/appraisal/appraisaloutline/framed/frame.htm

Williams, K. (2003). Understanding Media Theory. London: Arnold.

Young, L. (2011). Systemic functional linguistics. In Simpson, J. (ed.), The Routledge Handbook of Applied Linguistics. London: Routledge, pp. 625-637.

Zempi , I., \& Awan, I. (2016). Islamophobia: lived experiences of online and offline victimization. Bristol: Policy Press. https://doi.org/10.2307/j.ctt1t88zw7.12

\section{Copyrights}

Copyright for this article is retained by the author(s), with first publication rights granted to the journal.

This is an open-access article distributed under the terms and conditions of the Creative Commons Attribution license (http://creativecommons.org/licenses/by/4.0/). 